\title{
SOCIAL EMPLOYMENT OF WELFARE RECIPIENTS IN BELGIUM: AN EVALUATION 1
}

\author{
by \\ Bart Cockx - Université Catholique de Louvain² \\ Geert Ridder - Vrije Universiteit Amsterdam³
}

July 1996

\begin{abstract}
:
In Belgium welfare agencies are subsidized to employ welfare recipients for a period sufficiently long to entitle them to benefits of the contributory social insurance program. This type of employment is called Social Employment (SE). This paper investigates the effect of SE on the exit rate from welfare. We extend the minimum chi-square approach of Cockx (1995) for grouped duration data to deal with selection into SE at any instant during the welfare spell. Moreover, we introduce a specification error as in Amemiya and Nold (1975) to account for omitted variables, which may be correlated with the selection into SE. We show that a variable that is not correlated with the omitted variables, but affects the probability of selection into SE identifies the SE-effect, and we propose a consistent estimator of this effect that is free of selection bias. We argue that region is such a variable, because in Belgium regional governments determine the subsidy for SE, which affects the participation rate in SE by some political process without consideration of the average characteristics of the welfare recipients in their region. The empirical analysis discovers creaming in the selection process. Without correction for selectivity we find that SE reduces welfare dependency. After correction this conclusion is reversed. These results are in line with the incentives faced by the welfare agencies, that administer the program.
\end{abstract}

Keywords: Welfare, evaluation, duration data, grouping

\footnotetext{
${ }^{1}$ We are grateful for the research assistance provided by Annick Persoon. This project has been financed by several grants: first, by a Human Capital and Mobility Fellowship which enabled the first author to visit the Tinbergen Institute in Amsterdam during the first semester of 1994; second, by a grant $\left(\mathrm{n}^{\circ}\right.$ 30.1.92.237) of the Belgian Fund of Collective and Fundamental Research (F.K.F.O); finally, by a grant "Actions de Recherches Concertées" $\mathrm{n}^{\circ}$ 93/98-162 of the Ministry of Scientific Research of the Belgian French Speaking Community. We also thank the Centre of Economic Studies of the Katholieke Universiteit Leuven, the Tinbergen Institute, and IRES of the Universite Catholique de Louvain for the accommodation and the facilities provided. We thank the Minister of Health, Environment and Social Emancipation for access to the data and Frans Spinnewyn for his support in setting up this research project. Finally, we are grateful to Geert Dhaene, Thierry Magnac, Michel Mouchart, Bruno Van der Linden, and Marno Verbeek for their valuable comments. The usual disclaimer applies.

2 IRES, Université Catholique de Louvain, Place Montesquieu 3, B-1348 Louvain-la-Neuve, Belgium, phone: +32.10.47.34.39. E-mail: cockx@ires.ucl.ac.be.

${ }^{3}$ FEWEC, Vrije Universiteit Amsterdam, De Boelelaan 1105, 1081 HV Amsterdam, The Netherlands, phone: +31.20.444.60.19. E-mail: gridder@econ.vu.nl.
} 


\section{Introduction}

In Belgium the welfare system is a safety net for those who for some reason are not covered by social insurance and whose income falls short of the legally determined minimum, the Minimum Income Guarantee $(\mathrm{MIG})^{1}$. If they pass a means test, individuals in need can claim a supplement to their income up to the MIG level at the welfare agency $(\mathrm{WA})^{2}$ of their municipality. Legislation stipulates that these WA's may employ welfare recipients in order to entitle them to social insurance benefits. In particular, if this employment lasts sufficiently long it entitles the employee to unemployment benefits. This paper evaluates this employment by the WA, which is referred to as social employment (SE).

SE can be viewed as a type of subsidized employment, be it a rather special one. There is evidence (see Bassi and Ashenfelter 1986, Ridder 1986, Gueron 1990, Gueron and Pauly 1991, Moffitt 1992, Bell and Orr 1994) that subsidized employment can realize substantial economic benefits in the form of increased earnings and employment rates and lower welfare dependency for participants ${ }^{3}$. Sufficient training and assistance seem to be requirements for success though (Gueron 1990, p.91-93). Moreover, as subsidized employment is expensive these studies are not conclusive regarding its cost effectiveness. Evaluation studies of SE in Belgium are consistent with these findings, as they conclude that SE only has positive employment effects, if the participants are assisted and trained during employment. However, these studies have methodological flaws, that make it hard to draw firm conclusions.

Van de Velde (1990) reports poor results for SE. She found that in 1986 only 8\% of the participants held a regular job immediately after SE. The remainder became entitled to a social insurance allowance. Moreover, in total $48 \%$ remained unemployed during all 3 years after SE. This finding need not be in conflict with the evidence cited above, because in 1986 SE was hardly accompanied by any assistance or training. A problem with her analysis is that she did not compare these fractions with those for nonparticipants. Therefore, it is conceivable that the employment rate was even smaller for the latter group. More recent research by Dehaes (1994) finds that participants in SE are indeed more likely to leave welfare. However, that study does not correct for the biases induced by sample design ${ }^{4}$ and treatment selection.

Correction for the latter bias is essential. Participants in SE have different characteristics than non-participants. Garcia (1990) finds that participants are younger, more educated and have more labor market experience than non-participants. Moreover, the WA may select participants on the basis of characteristics, which we, as researchers, can not observe. To the extent that the researcher fails to correct for these differences, the observed effect may merely reflect these differences, instead of the effect of SE.

One evaluation study makes an attempt to correct for selective participation. Wouters, Van Meensel and Nicaise (1994) evaluate pilot projects in which training and intensive assistance complement SE. By matching participants and non-participants on a number of observable characteristics, they try to minimize the effect of selection into the

\footnotetext{
1 "het Bestaansminimum" / "le Minimex".

2 "het OCMW" / "le CPAS".

3 Ridder studies Dutch programs. All other studies evaluate US programs.

4 In particular, she did not take the length-biased nature of the sample into account, nor did she adequately treat individuals experiencing multiple welfare spells.
} 
programs. Program participants are found to have higher employment rates than nonparticipants, even in the long run.

In the present study we try to deal with the biases that have affected previous evaluations of SE. We estimate the impact of SE on the propensity to leave welfare. In order to avoid misinterpretation, it is important to realize that exit out of welfare can be to a number of destinations. We can deduce from the findings of Dehaes (1994, p. 119 and 128 ) that $26 \%$ of the terminations are due to a change in labor market status $5,35 \%$ to entitlement to other social benefits, $19 \%$ to moving to another municipality, $11 \%$ to a change in the family composition ${ }^{6}, 4 \%$ to the WA challenging the entitlement to welfare and finally $4 \%$ to other reasons. Our data do not allow us to distinguish between these various exits. Hence, a positive effect of SE on the total exit rate from welfare need not correspond to a larger transition rate into employment outside the WA.

We have to allow for the possibility of selective participation in SE. Recent research (see LaLonde 1986 or Fraker and Maynard 1987) has thrown doubt on the capacity of non-experimental methods to correct for selection bias. Estimates are found to be sensitive to model specification and estimation method. This line of research asserts that the selection bias can only be controlled for if one disposes of data emerging from an experiment.

Experiments can be controlled or natural (cf. Angrist 1992). They are controlled if they are designed by researchers in an attempt to uncover causal relationships either by controlling the environment or by randomizing the intervention of interest. Natural experiments usually are not generated for research purposes, but are the by-product of some exogenous change in the assignment process. In controlled experiments there remains a risk of biased treatment effects (cf. Burtless and Orr 1986 or Heckman 1992), because the experiment interferes with the normal operation of the program. This critique does not apply to natural experiments. The analysis of natural experiments has therefore been advocated in the recent evaluation literature (cf. Krueger 1990, Meyer 1989, and Meyer, Viscusi and Durbin 1990, Angrist 1990, Angrist and Krueger 1991, Imbens and Van der Klaauw 1993, Imbens and Angrist 1994 and Card and Krueger 1994). Meyer (1995) gives an extensive discussion of the role of experiments in the evaluation of social programs.

Angrist (1992, p.1-3) distinguishes between two types of natural experiments. The first type exploits unusual institutions or circumstances that lead to an exogenous manipulation of the treatment assignment. The second type of natural experiment is a change in policy. One collects data before and after a new policy has been implemented and hopes that the policy change is the only change that has occurred.

As we show below, the subsidy for SE differs between regions and between municipalities of different population size. If it is true that the subsidy levels differ as a consequence of a political process that sets these levels without taking the probability of leaving welfare into account, then this process induces a natural experiment of the first type. There is variation in the assignment to the treatment group which is unrelated to the outcome of interest, the probability of leaving welfare.

Krueger (1990), Meyer (1989), and Meyer, Viscusi and Durbin (1990) analyzed duration data that were generated by a natural experiment. Their approach can not be

\footnotetext{
5 This refers to events such as reemployment, a transition from a part-time to a full-time job, an increase of self-employment earnings, etc.

6 This refers to events such as marriage to or cohabitation with a partner with a sufficiently high income, moving into the house of parents or children with sufficient means, etc.
} 
used in the evaluation of SE. First, because censoring is important and we must allow for observed differences, parametric distributional assumptions are needed in their approach (see Krueger 1990, p.14). Therefore, the critique of LaLonde (1986) and Fraker and Maynard (1987) applies. Second, their approach can not account for selection into SE during welfare spells. They assume that individuals are selected into the treatment group prior to entry into the state of interest, in our case welfare. WA's, however, employ and therefore select welfare recipients at some instant during the welfare spell.

To avoid restrictive distributional assumptions we discretize the data and employ a flexible specification for discrete duration data, as used in Cockx (1995). We explicitly allow for unobservable variables. If these unobservable variables are correlated with participation in SE, there is selective participation. If there is variation in the rate of participation, that is independent of the variation in the probability of leaving welfare, the true effect of SE is still identifiable. The flexible discrete duration model can easily allow for competing risks. This is important to deal with selection into SE during welfare, and with censoring of SE and welfare spells. An additional advantage of the flexible discrete duration model is that it can be estimated with (weighted) least squares, so that it can be used with large data sets, as the administrative records analyzed in this study.

In the following section we discuss the main features of SE. In Section 3 we explain the nature of the natural experiment. The following section describes the data. Section 5 presents the benchmark model that we use to estimate the effect of SE on the welfare spells. Section 6 discusses the robustness of the results. The final section contains the conclusions.

\section{The Main Features of Social Employment}

The law of July 1976 regarding the WA's in Belgium stipulates that an WA may employ an individual with an employment record that is insufficient to qualify for social benefits, more specifically unemployment benefits derived from the contributory social insurance system. Unemployment benefits are only paid to workers who, within a specified period prior to their claim, have been employed for at least 75 days if younger than 18, and up to 600 days if older than 50 (Van Langendonck 1991, p. 450).

The possibility to employ welfare recipients for this purpose brought legislation into agreement with the principle that social assistance offers relief only if the main social insurance system fails to do so. The national and regional ${ }^{7}$ authorities have gradually widened the scope of SE to a means of enhancing the socio-professional integration of the poor. This was reflected in increasing levels of financial support. The regional authorities subsidize SE in Flanders since 1983 and in the Walloon provinces since 1989. The central authorities finance $50 \%$ of the MIG paid by the local WA. Since 1985 the WA remains entitled to this subsidy if it socially employs the welfare recipient, and since January 1993 the subsidy is up to $100 \%$ of the MIG.

\footnotetext{
7 Readers who are familiar with the Belgian institutional setting will notice that we use "regional" in a loose sense. As such, we can divide Belgium into 4 regions: "Flanders", referring to the Flemish (Dutch) speaking community in the North; "the Walloon provinces", referring to the French speaking community in the South; "Brussels", referring to the region of the bilingual community of the capital city; "the German speaking community" in the East. Given the marginal importance of the latter region, we ignore it in the sequel.
} 
SE was not only stimulated by increased financial support. During 1987 and 1988 the federal minister of social integration launched a number of pilot projects to investigate whether SE could enhance the socio-professional integration of the poor (see Caymax, 1988, Dechamps, 1988 and Lescrauwaet, 1988). Based on the conclusions of this research and on the observation that participants in SE often returned to unemployment (Van de Velde 1990), new projects that provided intensive assistance and training on the job, were initiated in 1989 (Van Meensel and Heeman 1992). The scale of these projects was gradually increased over time. By $199310 \%$ of the Belgian welfare agencies was involved in these projects. The participating welfare agencies accounted for more than $20 \%$ of the welfare population (Wouters, Van Meensel and Nicaise 1994, p.1-2).

Van de Velde (1989) demonstrates that SE is concentrated in the community services that the WA offers to the general public. These community services consist of domestic services to households, such as care, meal provision, cleaning, and to institutions, i.e. nurseries, hospitals, elderly homes, etc. These jobs require few qualifications. Women are typically (95\%) employed in the domestic services provided by the WA. This work involves cleaning, cooking, washing and ironing. Men are required to do all kinds of odd jobs (37\%), to maintain roads or to plant vegetation (13\%), to help in the kitchen (10\%), to do administrative work (10\%) (see Van de Velde, p.55). The work is typically remunerated at the minimum wage. It should be noted that employment is mandatory since the receipt of welfare benefits is conditional on the willingness to work.

WA's can save on outlays by employing welfare recipients. An example clarifies this point ${ }^{8}$. Consider a welfare recipient living alone somewhere in Flanders in January 1989. The net monthly cost of SE for this individual is the cost of the minimum wage for the employer (=49,354 Belgian Francs) minus the central authorities' subsidy amounting to $50 \%$ of the $\mathrm{MIG}(=8,152 \mathrm{BF})$ and the regional authorities' subsidy $(=30,500 \mathrm{BF})$ : $10,702 \mathrm{BF}$. Moreover, during the initial period of SE, during which the participant would otherwise depend on welfare, the WA no longer needs to pay welfare benefits and therefore saves additionally at least ${ }^{9} 50 \%$ of the MIG $(=8,152 \mathrm{BF})$ minus the regional subsidy for welfare $(=1,141 \mathrm{BF})$, that is $7,011 \mathrm{BF}$. This implies that employing a worker who initially produces goods and services with a value of more than 3,691 BF per month and later on of more than 10,702 BF per month, in SE is financially attractive to the WA. The WA need not worry about costs after SE, because after SE welfare recipients are entitled to social insurance benefits, and hence will not depend financially on the WA. We conclude that SE can result in savings for WA's. These savings are larger if the WA "creams" the most productive recipients for participation in the program.

This observation is not only valid for the specific example. However, the magnitude of the savings differs with the level of the $\mathrm{MIG}^{10}$, the time period and the region. For instance, Brussels does not provide a specific subsidy for SE and due to the growing success of the program in Flanders the level of the subsidy per participant declined over time. In the case of a lower subsidy the WA can maintain savings by being more selective in the choice of participants. The specific subsidy rules provide no incentive to the WA to use SE as a means to integrate welfare recipients in the labor

\footnotetext{
8 The figures in the example are taken from an internal document of a WA to which we had access.

9 WA's can offer a supplement to the MIG financed out of their own means.

10 The level of the MIG is different according to household type. Legislation distinguishes between singles living alone, singles living with dependent children, cohabiting individuals and cohabiting married couples.
} 
market. Any effort to this effect will only increase its expenditures. Consequently, the findings of Van de Velde (1990, p. iv), that SE was hardly accompanied by training and assistance and that the WA's encouraged only $6 \%$ of the participants to apply for another job, are not surprising.

On the basis of these observations, we conclude that one can hardly expect SE to enhance integration and to reduce welfare dependency. The new programs introduced in January 1989, in which SE is supplemented by intensive assistance and training may have different effects. However, since participation by WA's in these programs is voluntary, they are unlikely to be implemented by a majority of the WA's as long as subsidy rules allow WA's to save on outlays by hampering the professional integration. In the remainder of this study we investigate whether these claims are supported by the data.

\section{Exogenous Variation in Participation}

In the introduction we mentioned that in Belgium the regional authorities provide specific subsidies for SE of welfare recipients. These subsidies differ between regions. In this section we show that these differences induce differences in participation rates in SE between regions. Moreover, we shall argue that the levels of the subsidy are exogenously determined, i.e. that they are determined without taking the exit rate from welfare into account. Hence, the variation in the participation rate by region can be considered to be induced by a natural experiment.

In order to understand the subsidy mechanism it is important to note that the provision of community services is the responsibility of the regional authorities. SE is regarded as a community service offered to welfare recipients. The regional authorities dispose of a fund ${ }^{11}$ from which particular community services provided by the WA's of a region are paid for. This fund is financed out of national tax proceeds. Its size is set according to fixed rules and it is distributed between the regions according to objective criteria as the size of the area, the size of the population and the tax proceeds in the region. The regional authorities cannot influence the size of this fund. They can only decide on the way in which they allocate this fund to the different types of community services offered by the WA's.

SE is one type of community service that is subsidized out of this fund. Table 1 indicates how the proportion ${ }^{12}$ of the budget allocated to SE differs between Brussels, Flanders and the Walloon provinces for the 1986-92 period. Note that Brussels provides no specific subsidy to SE.

\section{INSERT TABLE 1 APPROXIMATELY HERE}

From this table we conclude that the fraction of the regional fund allocated to SE is larger in Flanders than in the Walloon Provinces and that the fraction in the Walloon Provinces in turn is larger than in Brussels. According to Cockx (1995) welfare recipients living in Brussels are most likely to exit from welfare, followed respectively by

\footnotetext{
11 "Bijzonder Fonds voor Maatschappelijk Welzijn".

12 These proportions are the desired ones and do not necessarily coincide with those that are realized ex post.
} 
those living in Flanders and in the Walloon Provinces. Hence, the fraction allocated to $\mathrm{SE}$ is certainly not positively related to the exit rate from welfare.

There are further reasons to believe that the political process sets subsidy levels independently of the exit rate from welfare. First, the regional authorities are not financially responsible for the benefits paid to welfare recipients. This is a responsibility of the national and the municipal authorities. So, even if one believes that SE can save outlays on welfare by reducing the length of welfare spells, regional governments have no financial incentive to stimulate SE to realize these savings.

On the other hand, the SE-subsidy can be seen as a subsidy aimed at fighting poverty. However, SE is one of many community services that can be used to this effect. Hence, even if the choice of the regional authorities is influenced by the extent of poverty in their region (which remains to be proven) and therefore by the exit rate from welfare, the decision to subsidize SE rather than other community services depends on the perceived relative costs and benefits of the various programs. It is hard to believe that the relative costs (and the relative effects on the size of the welfare population ${ }^{13}$ ) differ much between the regions, and hence the variation in the fraction allocated to SE must reflect the political preference for $\mathrm{SE}$ in the regions, i.e. exogenous variation in the perceived attractiveness of SE as a means to reduce poverty. We conclude that the fraction of the regional fund allocated to SE is determined independently of the outcome of interest in this study, the probability of leaving welfare. On the other hand, because of the savings that the WA's can realize by employing welfare recipients, participation rates in SE are affected by the subsidy level. Hence, the political process induces exogenous variation in participation rates between regions, and this exogenous variation can be used to identify the effect of SE on the exit rate from welfare.

In using this exogenous variation, we are confronted with a complication: the difference in the probability of leaving welfare between regions is not exclusively determined by the difference in the participation rates in SE. It is well known that in the period considered the labor market conditions in Flanders were more favorable than in the Walloon provinces. To identify the effect of SE in the presence of regional effects on the exit rate from welfare, we must make an additional assumption. To be specific, we assume that the regional effects are identical for participants and non-participants, i.e. we assume that there is no interaction between the region and the SE status. Differences-indifferences estimators require a similar lack of interaction between the treatment status and the other stratification variable Krueger 1990, Angrist 1992, 1993).

\section{The Data}

We analyze administrative data on recipients of the MIG that has been collected since June 1987 by the Ministry of Social Integration. From these data we can calculate the length of welfare and SE spells for all MIG recipients, who claim benefits after June 1st 1987. In the analysis we consider only spells that have started in the period June 1987 July 1990. On July 1st 1990 additional measures to stimulate the socio-professional integration of welfare recipients were introduced. To obtain an estimate of the effect of $\mathrm{SE}$, we do not consider spells after this date. We only consider welfare recipients who

13 One could argue that benefits of SE are larger in a high unemployment region. However, according to Table 1 the low unemployment region, Flanders, has the largest subsidy for SE. 
were younger than fifty at the start of the welfare spell. For older recipients the integration is less relevant.

Table 2 summarizes some characteristics of the population under consideration. As the data were gathered for administrative purposes and not for analysis, the information is limited. The first column refers to all welfare spells, the second refers to those spells in which some period was spent in SE.

\section{INSERT TABLE 2 APPROXIMATELY HERE}

In contrast to Garcia (1990) we do not find an age difference between SE participants and non-participants. This is a consequence of the restriction to welfare recipients younger than fifty. On the other hand, the overrepresentation of women among the socially employed is confirmed. In addition, individuals who are legally married but living alone, are overrepresented among the participants in SE. Furthermore, participants are more likely to be responsible for dependent children. The rate of participation in SE is larger in small municipalities and in Flanders.

A welfare spell is a spell during which the recipient either receives welfare benefits or is socially employed. The median spell length is 5 months. This is somewhat smaller than the number reported in Cockx (1995). The difference can be attributed to the exclusion of recipients older than fifty. Welfare spells of participants in SE are much longer. The median duration for this group is found to be 13 months. From this we cannot conclude, that participation in SE increases welfare dependency. Note that the median duration until selection into SE is 6 months. However, even if we subtract the time until selection, the median duration of participants $(=13-6=7$ months $)$ exceeds median duration of all welfare spells. If the exit rate from welfare decreases with the length of the spell, then this difference may be due to fact that post-SE welfare spells start after some time in welfare and for that reason have lower exit rates. In other words, participants have lower exit rates because of the time spent in welfare before selection into SE.

\section{Dealing with Bias: Discrete Durations, Competing Risks and Unobservables}

In the previous section we noted that a direct comparison of the exit rates from welfare between SE-participants and non-participants gives a biased estimate of the effect of SE. The first bias is due to the combination of selection into SE during the welfare spell and potential duration dependence of the exit rate. In this section we introduce a model for discrete duration data with competing risks that deals with this bias. By including observable characteristics of welfare recipients we also eliminate bias due to selection on observables. In Section 3 we have argued that WA's have an incentive to select relatively productive welfare recipients into SE. It is clear that WA's know more about these recipients than we do: it is difficult to assess the productivity of the welfare recipient on the basis of the few characteristics that we have at our disposal. Hence, we expect that selection into SE will be mainly on unobservables, and failure to correct for this selection biases the estimate of the effect. To deal with this selection bias we allow for an unobservable in the exit rate, just as in Amemiya and Nold's (1975) grouped logit model. This unobservable may differ between SE-participants and non-participants, as asserted 
in Section 3, but we assume that it does not differ, on average, between regions. This allows us to identify the effect of SE on the exit rate.

Durations can be modeled in continuous time or in discrete time. Following Prentice and Gloeckler (1978) and Cockx (1995) we choose a proportional hazards model, which is a continuous-time model, but because our duration data are grouped, we employ the grouped proportional hazards model. This model allows for a flexible specification of the duration dependence and gives, after a simple transformation of the dependent variable, a (heteroscedastic) linear regression model. It is straightforward to include unobservables in such a model. In particular, we do not need any assumption on the distribution of the unobservable, as required in models with continuously observed durations.

\subsection{Time-Varying Covariates and Competing Risks with Grouped Duration Data}

Let the duration data be grouped into $\mathrm{K}+1$ intervals: $\left[\mathrm{t}_{0}, \mathrm{t}_{1}\right), \ldots,\left[\mathrm{t}_{\mathrm{k}-1}, \mathrm{t}_{\mathrm{k}}\right), \ldots$, $\left[\mathrm{t}_{\mathrm{K}-1}, \mathrm{t}_{\mathrm{K}}\right),\left[\mathrm{t}_{\mathrm{K}}, \mathrm{t}_{\mathrm{K}+1}\right)$ of (possibly unequal) length $\Delta_{\mathrm{k}}=\mathrm{t}_{\mathrm{k}}-\mathrm{t}_{\mathrm{k}-1}$ with $\mathrm{t}_{0}=0, \mathrm{t}_{\mathrm{K}+1}=\infty$. In the simplest grouped duration model it is assumed (Prentice and Gloeckler 1979) that the (base-line) hazard $\lambda$ is constant on these intervals

$$
\lambda(\mathrm{t})=\lambda_{\mathrm{k}}, \quad \mathrm{t}_{\mathrm{k}-1} \leq \mathrm{t}<\mathrm{t}_{\mathrm{k}}
$$

Let $\mathrm{d}(\mathrm{t})$ be indicator of participation in SE at $t$. Note that the time-scale is the duration of the welfare spell. The time origin is the start of the spell. This is the time-scale used in the rest of this paper.

If we assume that the effect of SE on the exit rate is independent of $t$, then the exit rate $h$ becomes

$$
h(t)=\exp (\alpha d(t)) \lambda(t)
$$

Let $\mathrm{P}_{\mathrm{k}}$ be the conditional probability of exit in the $\mathrm{k}$-th duration interval $\left[\mathrm{t}_{\mathrm{k}-1}, \mathrm{t}_{\mathrm{k}}\right.$ ) given that the individual is on welfare at $\mathrm{t}_{\mathrm{k}-1}$. With (5.1) and (5.2) we have

$$
P_{k}=1-\exp \left(-\lambda_{k} \int_{t_{k-1}}^{t_{k}} \exp (\alpha d(s)) d s\right)
$$

This probability depends on the path of $d$ in the k-th duration interval. With grouped duration data this path is unknown. Hence it seems that we must make an assumption on this path. For instance, we may assume that exit from SE is only possible by leaving welfare, and that all selection into SE occurs at time $t_{k-1}$. Under these assumptions we only need to know the SE-status at the start of the k-th interval to determine $\mathrm{P}_{k}$ : the SEindicator is constant on the $\mathrm{k}$-th interval.

Such an assumption is counterfactual, because individuals may leave SE and remain on welfare, and they may be selected into $\mathrm{SE}$ at any point in the welfare spell. For that reason we make an alternative assumption, which is in the spirit of $(5.1)$. Let $\theta_{0}(t)$, $\theta_{1}(\mathrm{t})$ be the transition intensities into and out of SE at welfare duration $t$. As in (5.1) we assume that these intensities are piece-wise constant, and $\theta_{0 \mathrm{k}}, \theta_{1 \mathrm{k}}$ are the values taken on 
the k-th interval. We condition on the SE-status at the beginning of the k-th interval. Let $\mathrm{P}_{\mathrm{k}}^{\mathrm{WSE} \text {, OW }}$ be the conditional probability of leaving welfare in the $\mathrm{k}$-th duration interval and being in SE until exit from welfare given that the individual is on welfare and in SE at $\mathrm{t}_{\mathrm{k}-1}$. Analogously, let $\mathrm{P}_{\mathrm{k}}^{\mathrm{WNSE} \text {,OW }}$ be the conditional probability of leaving welfare in the $\mathrm{k}$ th duration interval and not being in SE until exit from welfare given that the individual is on welfare and not in SE at $\mathrm{t}_{\mathrm{k}-1}$. These probabilities are transition probabilities in the $\mathrm{k}$-th interval from the state 'welfare with SE (WSE)' to the state 'out of welfare (OW)' and from the state 'welfare without SE (WNSE)' to the state 'out-of-welfare (OW)'. With (5.1) and (5.2) we have

$$
\mathrm{P}_{\mathrm{k}}^{\mathrm{WSE}, \mathrm{OW}}=\int_{0}^{\Delta_{\mathrm{k}}} \lambda_{\mathrm{k}} \exp (\alpha) \exp \left(-\lambda_{\mathrm{k}} \exp (\alpha) \mathrm{s}\right) \exp \left(-\theta_{1 \mathrm{k}} \mathrm{s}\right) \mathrm{ds}
$$

$$
=\frac{\lambda_{\mathrm{k}} \exp (\alpha)}{\lambda_{\mathrm{k}} \exp (\alpha)+\theta_{1 \mathrm{k}}}\left[1-\exp \left(-\lambda_{\mathrm{k}} \exp (\alpha) \Delta_{\mathrm{k}}-\theta_{1 \mathrm{k}} \Delta_{\mathrm{k}}\right)\right]
$$

In a similar way we obtain

$$
\mathrm{P}_{\mathrm{k}}^{\mathrm{wSE}, \mathrm{WNSE}}=\frac{\theta_{1 \mathrm{k}}}{\lambda_{\mathrm{k}} \exp (\alpha)+\theta_{1 \mathrm{k}}}\left[1-\exp \left(-\lambda_{\mathrm{k}} \exp (\alpha) \Delta_{\mathrm{k}}-\theta_{1 \mathrm{k}} \Delta_{\mathrm{k}}\right)\right]
$$

The conditional probability of all other events is the complement of the sum of these probabilities.

For welfare recipients who are not in SE at the start of the k-th interval we have

$$
\mathrm{P}_{\mathrm{k}}^{\mathrm{WNSE}, \mathrm{OW}}=\frac{\lambda_{\mathrm{k}}}{\lambda_{\mathrm{k}}+\theta_{0 \mathrm{k}}}\left[1-\exp \left(-\lambda_{\mathrm{k}} \Delta_{\mathrm{k}}-\theta_{0 \mathrm{k}} \Delta_{\mathrm{k}}\right)\right]
$$

and

$$
\mathrm{P}_{\mathrm{k}}^{\mathrm{WNSE}, \mathrm{WSE}}=\frac{\theta_{0 \mathrm{k}}}{\lambda_{\mathrm{k}}+\theta_{0 \mathrm{k}}}\left[1-\exp \left(-\lambda_{\mathrm{k}} \Delta_{\mathrm{k}}-\theta_{0 \mathrm{k}} \Delta_{\mathrm{k}}\right)\right]
$$

The expressions (5.4)-(5.7) show that our model for selection into SE is equivalent to two competing risks models with piece-wise constant transition intensities: one for the origin state WSE and destination states OW and WNSE, and one for the origin state WNSE and destination states OW and WSE. Next, we discuss how we may obtain a linear regression model, if we transform the transition probabilities on the lefthand side of (5.4)-(5.7) appropriately.

\subsection{Modeling Grouped Durations with Competing Risks}

It will be convenient to attach numbers to the three states which were introduced in Section 5.1 
2. Welfare with SE

3. Out of welfare

In the sequel we identify the states by these numbers. We are interested in comparing the transition intensity from state 1 to state 3 with that from state 2 to state 3 . This identifies the effect of SE on the exit rate from welfare. State 3 is assumed to be an absorbing state. Our data do not allow us to observe multiple welfare spells.

Origin/destination states are indicated by superscripts $u, v$ and duration intervals and types of individuals by subscripts $k$ and $m$, respectively. We make the following assumptions on the transition intensities between the states

$$
\log \left(\mathrm{h}_{\mathrm{km}}^{\mathrm{uv}}\right)=\gamma_{\mathrm{k}}^{\mathrm{v}}+\beta_{\mathrm{m}}^{\mathrm{v}}+\alpha^{\mathrm{uv}}+\varepsilon_{\mathrm{km}}^{\mathrm{uv}}, \quad \mathrm{u}=1,2, \mathrm{v}=1,2,3 \neq \mathrm{u}
$$

There are $K+1$ duration intervals, where the last interval is open, and $M$ types. The duration effect $\gamma_{\mathrm{k}}^{\mathrm{v}}$, and the type effect are assumed to depend only on the destination state, i.e. they are the same for SE-participants and non-participants. We normalize the type effects and set $\beta_{1}^{\mathrm{v}}=0$. The parameter $\alpha^{\mathrm{uv}}$ gives the effect of SE on the exit rate from welfare. The effect is assumed to be independent of the type $m$. By definition $\alpha^{12}=\alpha^{21}=0$, and by normalization $\alpha^{13}=0$. Note that $\alpha^{23}$ is the parameter of interest. Finally, the $\varepsilon_{\mathrm{km}}^{\mathrm{uv}}$ are unobserved variables, which are similar to the specification errors introduced by Amemiya and Nold (1975) in their grouped logit model (see also Parks 1980). If we consider these unobserved variables as parameters, we obtain a saturated model. In the sequel we impose restrictions on the unobserved variables, by assuming that they are draws from some distribution that does not depend on some of its indices. The specification in (5.8) is a proportional hazards model for the continuous-time transition intensities. These are assumed to be constant on the duration intervals.

The specification allows for unobserved heterogeneity in the transition intensities. Unobservables may be important determinants of the transition intensities, because the number of included observed characteristics is small. Because unobservables may also be important for the selection into SE and correlation between unobservables in the transition intensities and in the selection process biases the estimate of the SE-effect, we must assess their contribution to the explanation of the transition intensities. Because the data are categorized, the unobservables vary between, but not within groups. Hence, the analogy between the group-specific unobserved heterogeneity in our model and the individual unobserved heterogeneity in continuously observed duration data is imperfect.

Under these assumptions the transition probability $\mathrm{P}_{\mathrm{km}}^{\mathrm{uv}}$, i.e. the probability of a transition of an individual of type $m$ from state $u$ to state $v$ in duration interval $k$, is equal to

$$
\mathrm{P}_{\mathrm{km}}^{\mathrm{uv}}=\frac{\mathrm{h}_{\mathrm{km}}^{\mathrm{uv}}}{\sum_{\mathrm{w}=1, \mathrm{w} \neq \mathrm{u}}^{3} \mathrm{~h}_{\mathrm{km}}^{\mathrm{uw}}}\left(1-\exp \left[-\sum_{\mathrm{w}=1, \mathrm{w} \neq \mathrm{u}}^{3} \mathrm{~h}_{\mathrm{km}}^{\mathrm{uw}} \Delta_{\mathrm{k}}\right\rceil\right), \mathrm{u}=1,2, \mathrm{v}=1,2,3 \neq \mathrm{u}
$$

This expression maps transition intensities to transition probabilities. The inverse mapping from transition probabilities to transition intensities is 
(5.10)

$$
\mathrm{z}_{\mathrm{km}}^{\mathrm{uv}}=\log \left(\frac{-\mathrm{P}_{\mathrm{km}}^{\mathrm{uv}} \log \left(\mathrm{P}_{\mathrm{km}}^{\mathrm{uu}}\right)}{\Delta_{\mathrm{k}}\left(1-\mathrm{P}_{\mathrm{km}}^{\mathrm{uu}}\right)}\right)=\log \left(\mathrm{h}_{\mathrm{km}}^{\mathrm{uv}}\right), \quad \mathrm{u}=1,2, \mathrm{v}=1,2,3 \neq \mathrm{u}
$$

with

$$
\mathrm{P}_{\mathrm{km}}^{\mathrm{uu}}=1-\sum_{\mathrm{w}=1, \mathrm{w} \neq \mathrm{u}}^{3} \mathrm{P}_{\mathrm{km}}^{\mathrm{uw}}
$$

the probability of staying in $u$ in the $\mathrm{k}$-th interval.

Let $\mathrm{r}_{\mathrm{km}}^{\mathrm{u}}$ be the number of individuals of type $m$ in state $u$ at the start of duration interval $k$, i.e. at time $\mathrm{t}_{\mathrm{k}-1}$, and let $\mathrm{q}_{\mathrm{km}}^{\mathrm{uv}}$ of these individuals make a transition from state $u$ to state $v$ in the $\mathrm{k}$-th duration interval. Then we estimate $\mathrm{P}_{\mathrm{km}}^{\mathrm{uv}}$ by

$$
\hat{\mathrm{P}}_{\mathrm{km}}^{\mathrm{uv}}=\frac{\mathrm{q}_{\mathrm{km}}^{\mathrm{uv}}}{\mathrm{r}_{\mathrm{km}}^{\mathrm{u}}}, \quad \mathrm{u}=1,2, \mathrm{v}=1,2,3 \neq \mathrm{u}
$$

Upon substitution of these estimates in the middle expression of (5.10), we obtain $\hat{\mathrm{z}}_{\mathrm{km}}^{\mathrm{uv}}$. If in (5.10) we replace the transition probabilities by their estimates, then the second equality does not hold exactly. However, a Taylor series expansion around $\mathrm{P}_{\mathrm{km}}^{\mathrm{uv}}$ yields

$$
\hat{\mathrm{z}}_{\mathrm{km}}^{\mathrm{uv}}=\log \left(\mathrm{h}_{\mathrm{km}}^{\mathrm{uv}}\right)+\mathrm{u}_{\mathrm{km}}^{\mathrm{uv}}, \quad \mathrm{u}=1,2, \mathrm{v}=1,2,3 \neq \mathrm{u}
$$

with

$$
\begin{aligned}
& \mathrm{u}_{\mathrm{km}}^{\mathrm{uv}}=\sum_{\mathrm{w}=1, \mathrm{w} \neq \mathrm{u}}^{3} \mathrm{~b}_{\mathrm{km}}^{\mathrm{uww}}\left(\hat{\mathrm{P}}_{\mathrm{km}}^{\mathrm{uw}}-\mathrm{P}_{\mathrm{km}}^{\mathrm{uw}}\right) \\
& \mathrm{b}_{\mathrm{km}}^{\mathrm{uww}}=\frac{1}{\mathrm{P}_{\mathrm{km}}^{\mathrm{uu}}-1}-\frac{1}{\mathrm{P}_{\mathrm{km}}^{\mathrm{uu}} \log \left(\mathrm{P}_{\mathrm{km}}^{\mathrm{uu}}\right)}+\delta_{\mathrm{ww}} \frac{1}{P_{\mathrm{km}}^{\mathrm{uv}}}
\end{aligned}
$$

and $\delta_{\mathrm{ww}}$ the Kronecker delta.

Conditional on $\mathrm{r}_{\mathrm{km}}^{\mathrm{u}}$ the random vector of the number of transitions of individuals of type $m$ from $u$ to states $\mathrm{v} \neq \mathrm{u}$ in the $\mathrm{k}$-th interval has a multinomial distribution with parameters $\mathrm{r}_{\mathrm{km}}^{\mathrm{u}}$ and $\mathrm{P}_{\mathrm{km}}^{\mathrm{u}}$, which is the vector of transition probabilities from state $u$ to states $\mathrm{v} \neq \mathrm{u}$ in interval $k$ for type $m$. Hence, we have for all $k, m$, and $\mathrm{u}=1,2$

$$
\mathrm{E}\left(\mathrm{u}_{\mathrm{km}}^{\mathrm{u}}\right)=0
$$

The disturbance in (5.13) has expectation 0 . The variance-covariance matrix of the vector $\mathrm{u}_{\mathrm{km}}^{\mathrm{u}}$ has typical element 


$$
\mathrm{E}\left[\left\{\left(\mathrm{b}_{\mathrm{km}}^{\mathrm{uvw}}\right)^{2}\left(\sum_{\mathrm{x}=1, \mathrm{x} \neq \mathrm{u}}^{3} \mathrm{P}_{\mathrm{km}}^{\mathrm{ux}}\left(1-\mathrm{P}_{\mathrm{km}}^{\mathrm{ux}}\right)-\sum_{\mathrm{x}=1, \mathrm{x} \neq \mathrm{u}}^{3} \sum_{\mathrm{y}=1, \mathrm{y} \neq \mathrm{x}}^{3} \mathrm{P}_{\mathrm{km}}^{\mathrm{ux}} \mathrm{P}_{\mathrm{km}}^{\mathrm{uy}}\right)+2 \mathrm{~b}_{\mathrm{km}}^{\mathrm{u}} \mathrm{P}_{\mathrm{km}}^{\mathrm{uu}}+\delta_{\mathrm{ww}}\left(1-\mathrm{P}_{\mathrm{km}}^{\mathrm{uv}}\right) / \mathrm{P}_{\mathrm{km}}^{\mathrm{uv}}-\left(1-\delta_{\mathrm{vw}}\right)\right\} / \mathrm{r}_{\mathrm{km}}^{\mathrm{u}}\right\rceil
$$

with $\mathrm{v}, \mathrm{w}=1,2,3 \neq \mathrm{u}$, and where the expectation is taken with respect to the distribution of $\mathrm{r}_{\mathrm{km}}^{\mathrm{u}}$. A consistent estimate is obtained by omitting the expectation and replacing the transition probabilities by their estimates.

Upon substitution of (5.8) into (5.13) we obtain a linear regression model. More precisely, we obtain for each origin state $\mathrm{u}=1,2$ two regression equations that correspond to the two destination states $\mathrm{v}=1,2,3 \neq \mathrm{u}$

$$
\hat{\mathrm{z}}_{\mathrm{km}}^{\mathrm{uv}}=\gamma_{\mathrm{k}}^{\mathrm{v}}+\beta_{\mathrm{m}}^{\mathrm{v}}+\alpha^{\mathrm{uv}}+\varepsilon_{\mathrm{km}}^{\mathrm{uv}}+\mathrm{u}_{\mathrm{km}}^{\mathrm{uv}}, \quad \mathrm{v}=1,2,3 \neq \mathrm{u}, \quad \mathrm{u}=1,2
$$

We assume that the $4 \mathrm{xMxK}$ unobserved variables are random variables ${ }^{14}$ with a joint distribution such that

$$
\begin{aligned}
& \mathrm{E}\left(\varepsilon_{\mathrm{km}}^{\mathrm{uv}}\right)=0 \\
& \mathrm{E}\left(\varepsilon_{\mathrm{km}}^{\mathrm{uv}} \varepsilon_{\mathrm{k}^{\prime} \mathrm{m}^{\prime}}^{\mathrm{u}^{\prime} \mathrm{w}}\right)=\delta_{\mathrm{kk}} \delta_{\mathrm{mm}} \delta_{\mathrm{uu}} \sigma^{\mathrm{uvw}}
\end{aligned}
$$

The unobserved variables corresponding to different duration classes, types, and origin states are assumed to be independent. The unobserved variables corresponding to different destination states may be correlated. Note that the disturbances $u_{\mathrm{km}}^{\mathrm{uv}}$ have the same pattern of zero correlations. Hence for origin state $u$ and for duration interval $k$ and type $m$, the distribution of the 2-vector of disturbances of the two regression equations (5.18) with $\mathrm{v}=1,2,3 \neq \mathrm{u}, \mathrm{v}_{\mathrm{km}}^{\mathrm{u}}$, which is the sum of the unobserved group effect and the approximation error has a variance-covariance matrix with typical element $\sigma^{\mathrm{uvw}}+\mathrm{s}_{\mathrm{km}}^{\mathrm{uvw}}$ with $\mathrm{v}, \mathrm{w}=1,2,3 \neq \mathrm{u}$. We denote this $2 \times 2$ matrix by $\mathrm{V}_{\mathrm{km}}^{\mathrm{u}}$. This completes the specification of the regression equations.

The regression equations (5.18) are a set of equations with heteroscedastic and correlated disturbances. Under assumption (5.19) which in particular implies that there are no unobserved differences in the exit rates of SE-participants $(u=2, v=3)$ and nonparticipants $(\mathrm{u}=1, \mathrm{v}=3)$, we can estimate the parameters of these equations by OLS, or more efficiently by GLS. Because we do not observe the transitions that occur in the open $\mathrm{K}+1$-th duration interval, we omit the regression equations that correspond to that interval. As a result, we have $\mathrm{MxKx} 2 \mathrm{x} 2$ equations. If we order the regressions by $m, k, u$, $v$, in this order, we obtain a block-diagonal variance-covariance matrix of the $\mathrm{MxKx} 2 \times 2$ vector of disturbances with the diagonal blocks being $2 \times 2$ matrices $\mathrm{V}_{\mathrm{km}}^{\mathrm{u}}$.

The feasible GLS procedure consists of two steps. In the first step we use OLS to estimate the $3 \mathrm{xK}+3 \mathrm{x}(\mathrm{M}-1)+1$ parameters $\gamma_{\mathrm{k}}^{\mathrm{v}}, \mathrm{k}=1, \ldots, \mathrm{K}, \mathrm{v}=1,2,3$,

14 The assumption that the omitted variables are random is analogous to the treatment of unobserved heterogeneity in duration (and other) model. The expectation is with respect to the distribution of the omitted variables. 
$\beta_{\mathrm{m}}^{\mathrm{v}}, \mathrm{m}=2, \ldots, \mathrm{M}, \mathrm{v}=1,2,3$, and $\alpha^{23}$. Next, we estimate the $2 \times 2$ variance-covariance matrix of the unobserved group effects by

$$
\hat{\sigma}^{\mathrm{uvw}}=\frac{1}{\mathrm{MK}}\left\{\sum_{\mathrm{m}=1}^{\mathrm{M}} \sum_{\mathrm{k}=1}^{\mathrm{K}}\left[\hat{\mathrm{v}}_{\mathrm{km}}^{\mathrm{uv}} \hat{\mathrm{v}}_{\mathrm{km}}^{\mathrm{uw}}-\hat{\mathrm{s}}_{\mathrm{km}}^{\mathrm{uvw}}\right]\right\}
$$

with $\hat{\mathrm{V}}_{\mathrm{km}}^{\mathrm{uv}}$ the residuals of the regression (5.18), and $\hat{\mathrm{s}}_{\mathrm{km}}^{\mathrm{uvw}}$ the estimate of (5.17). Substitution of this consistent estimate gives a consistent estimate of $\mathrm{V}_{\mathrm{km}}^{\mathrm{u}}$, which is used in the second step of the feasible GLS procedure.

Because we have grouped data, we can use a $\chi^{2}$-goodness-of-fit test to evaluate the specification of the model. Let $\hat{v}$ be the $4 \mathrm{KM}$-vector of residuals of the regression equation (5.18) ordered by $k, m, u, v$, in that order. Let the estimated variancecovariance matrix of the disturbances in (5.18) be denoted by $\hat{V}$. This is a block diagonal matrix, which simplifies the computation of its inverse. Under the assumption that the model is correctly specified we have that $\hat{v}^{\prime} \hat{V}^{-1} \hat{v}$ follows a $\chi^{2}$-distribution with 4KM-3K-3(M-1)-1 degrees of freedom.

\subsection{Estimation Results}

The estimation results for model (5.18) are reported in Table 3. Durations are measured in months. For the duration intervals we have chosen $\{[0,3),[3,6),[6,12),[12,24)\}$. There are three types that correspond to the three regions: Flanders, Walloon Provinces and Brussels. Hence, $\mathrm{M}=3, \mathrm{~K}=4$, so that we have 48 empirical hazard estimates and 19 regression parameters.

\section{INSERT TABLE 3 APPROXIMATELY HERE}

The estimator (5.21) gives negative estimates for the variances of the unobserved group effects corresponding to the transitions from state 1 tot state 2 and from state 2 to state 1. Following Parks (1980, p.299, footnote 5) we set these variances to 0. Hence, these unobserved group effects are set to 0 , and we have $\sigma^{123}=\sigma^{213}=0$. We only find an unobserved group effect in the transitions from welfare with SE and welfare without SE to out-of welfare.

Table 2 above suggested that SE decreases the exit rate from welfare. Table 3, which corrects for the timing of selection and the resultant lower exit rate due to the duration dependence of the exit rate, leads to the opposite conclusion: participation in $\mathrm{SE}$ increases the exit rate. Indeed, we find that the exit rate from welfare decreases significantly with the time spent in welfare, which explains the change in sign of the SE effect. Before we accept this result, we must control for the potential selectivity of the selection into SE. It may be that the unobserved characteristics of the participants are more favorable to exit than those of the non-participants. As argued in Section 2 WA's have an incentive to select welfare recipients with favorable characteristics. If this is true, then the distribution of the unobserved determinants of the exit rates $\varepsilon_{\mathrm{km}}^{\mathrm{uv}}$ depends on the transition. In particular, creaming implies that $\mathrm{E}\left(\varepsilon_{\mathrm{km}}^{23}\right)>\mathrm{E}\left(\varepsilon_{\mathrm{km}}^{13}\right)$, and as a result the effect of participation in SE is overestimated. 
Note that the goodness-of-fit test leads to a rejection of the model. Therefore, in Table 4 we let the SE-effect depend on the duration interval $k$. This is a deviation from the usual proportional hazards specification, where such a dependence is excluded. However, it is well-known, e.g. Lancaster (1990, p.64-65), that within-group heterogeneity makes the SE-effect duration dependent. More specifically, within-group heterogeneity induces a trend toward 0 in this effect. Hence, making the SE-effect dependent on $k$ provides a check on the presence of within-group heterogeneity.

\section{INSERT TABLE 4 APPROXIMATELY HERE}

There is another reason that the SE-effect may depend on $k$. In (5.8) the duration is the time spent in welfare, with or without SE. If the WA benefits from employing welfare recipients, it is likely that it discourages short spells in SE. The duration-dependent SEeffect captures the dependence of the exit rate from welfare with SE on the time spent in SE. The estimation results show that the goodness-of-fit test does not reject the model, and that the effect of SE increases with $k$. This is consistent with dependence on the time spent in SE, but not with within-group unobserved heterogeneity. In the sequel we are concerned with the average effect of SE during a spell in SE, and hence we shall only report the results with the SE-effect independent of $k$.

\subsection{Correcting for Selection on Unobservables}

In Section 5.1 we assumed that the omitted variables in the transition intensities are uncorrelated with participation in SE. Of course, this assumption is automatically satisfied, if there are no omitted variables. However, the estimates of $\sigma^{\mathrm{u} 33}, \mathrm{u}=1,2$ indicate that for the relevant transition intensities there are unobserved group effects. Hence, the estimated effect of SE in Table 3 may be biased because of the correlation between these unobservables and the SE indicator. In particular, if the WA's have indeed an incentive to select the most productive welfare recipients into SE, we expect that $\mathrm{E}\left(\varepsilon_{\mathrm{km}}^{23}\right)>\mathrm{E}\left(\varepsilon_{\mathrm{km}}^{13}\right)$.

In our model, the $\varepsilon_{\mathrm{km}}^{\mathrm{uv}}$ are unobserved group effects. Because we observe all welfare spells that start between June 11987 and July 11990 , the frequency of $\varepsilon_{\mathrm{km}}^{\mathrm{uv}}$ in the population is known and given by $\mathrm{f}_{\mathrm{km}}^{\mathrm{u}}$. Hence, we have

$$
\mathrm{E}\left(\varepsilon_{\mathrm{km}}^{\mathrm{u} 3} \mid \mathrm{k}, \mathrm{m}\right)=\sum_{\mathrm{u}=1}^{2} \frac{\mathrm{f}_{\mathrm{km}}^{\mathrm{u}}}{\mathrm{f}_{\mathrm{km}}} \varepsilon_{\mathrm{km}}^{\mathrm{u} 3}=\eta_{\mathrm{km}}
$$

Note that the expectation in (5.22) is the average over all individuals that entered welfare in the observation period. It should be distinguished from the expectation with respect to the distribution of the unobserved group effects, that reflects our uncertainty with respect to the value taken by $\varepsilon_{\mathrm{km}}^{\mathrm{uv}}$ for a particular $k, m, u, v$. Taking the conditional expectation on both sides of the regression (5.18) we obtain, using (5.22) 
$$
\hat{\mathrm{z}}_{\mathrm{km}}^{3}=\sum_{\mathrm{u}=1}^{2}\left(\frac{\mathrm{f}_{\mathrm{km}}^{\mathrm{u}}}{\mathrm{f}_{\mathrm{km}}}\right) \hat{z}_{\mathrm{km}}^{\mathrm{u} 3}=\gamma_{\mathrm{k}}^{3}+\beta_{\mathrm{m}}^{3}+\alpha^{23}\left(\frac{\mathrm{f}_{\mathrm{km}}^{2}}{\mathrm{f}_{\mathrm{km}}}\right)+\eta_{\mathrm{km}}+\sum_{\mathrm{u}=1}^{2}\left(\frac{\mathrm{f}_{\mathrm{km}}^{\mathrm{u}}}{\mathrm{f}_{\mathrm{km}}}\right) \mathrm{u}_{\mathrm{km}}^{\mathrm{u} 3}
$$

In (5.23) $f_{k m}^{2} / f_{k m}$ is the fraction of welfare recipients in $k, m$ that participate in SE. To estimate $\alpha^{23}$ from this regression we must restrict the $\eta_{\mathrm{km}}$. In (5.23) the $\eta_{\mathrm{km}}$ are unrestricted interaction effects, that can not be distinguished from $\mathrm{f}_{\mathrm{km}}^{2} / \mathrm{f}_{\mathrm{km}}$. In the sequel we assume that the $\eta_{\mathrm{km}}$ are draws from a distribution with (here the expectation reflects again our uncertainty with respect to the value taken by $\eta_{\mathrm{km}}$ )

$$
\mathrm{E}\left(\eta_{\mathrm{km}}\right)=\mu_{\mathrm{k}}, \quad \operatorname{Var}\left(\eta_{\mathrm{km}}\right)=\sigma^{33}
$$

Without loss of generality we can set the $\mu_{\mathrm{k}}$ equal to 0 by adding these to the duration effects $\gamma_{\mathrm{k}}^{3}$. The substantive assumption embodied in (5.24) is that $\mathrm{E}\left(\eta_{\mathrm{km}}\right)=\mathrm{E}\left(\eta_{\mathrm{km}}\right)$, i.e. on average $\eta_{\mathrm{km}}$ does not depend on $m^{15}$. In Section 3 we argued that the variation in the participation in SE between regions reflects exogenous differences in the political preference for SE. If that is correct, then (5.24) is satisfied. Hence, we can treat the $\eta_{\mathrm{km}}$ in the same way as the unobserved group effects in the regression (5.18).

In (5.18) we have four regression equations for each $k, m$. In (5.23) two of those are combined, so that we have in total $3 \times \mathrm{KxM}$ equations. If we order these equations by $m, k$ and for each such pair in the order transition from 1 to 2 , from 2 to 1 , combined 1 and 2 to 3 , then the variance matrix of the $3 \times \mathrm{KxM}$ vector of disturbances is blockdiagonal with blocks

$$
\left[\begin{array}{ccc}
\sigma^{122}+\mathrm{s}_{\mathrm{km}}^{122} & 0 & \sigma^{123}+\left(\mathrm{f}_{\mathrm{km}}^{1} / \mathrm{f}_{\mathrm{km}}\right) \mathrm{s}_{\mathrm{km}}^{123} \\
0 & \sigma^{211}+\mathrm{s}_{\mathrm{km}}^{211} & \sigma^{213}+\left(\mathrm{f}_{\mathrm{km}}^{2} / \mathrm{f}_{\mathrm{km}}\right) \mathrm{s}_{\mathrm{km}}^{213} \\
\cdots & \ldots & \sigma^{33}+\sum_{\mathrm{u}=1}^{2}\left(\mathrm{f}_{\mathrm{km}}^{\mathrm{u}} / \mathrm{f}_{\mathrm{km}}\right)^{2} \mathrm{~s}_{\mathrm{km}}^{\mathrm{u} 33}
\end{array}\right]
$$

In the two-step procedure we first use OLS to estimate the residuals. Next, $\sigma^{122}$ and $\sigma^{211}$ are estimated as in (5.21). If we denote the OLS residuals of (5.23) by $\hat{\mathrm{v}}_{\mathrm{km}}^{3}$, then we have

$$
\hat{\sigma}^{123}=\frac{1}{\mathrm{MK}}\left\{\sum_{\mathrm{m}=1}^{\mathrm{M}} \sum_{\mathrm{k}=1}^{\mathrm{K}}\left[\hat{\mathrm{v}}_{\mathrm{km}}^{12} \hat{\mathrm{v}}_{\mathrm{km}}^{3}-\left(\mathrm{f}_{\mathrm{km}}^{1} / \mathrm{f}_{\mathrm{km}}\right) \hat{\mathrm{S}}_{\mathrm{km}}^{123}\right]\right\}
$$

with an analogous estimator for $\sigma^{213}$, and

$$
\hat{\sigma}^{33}=\frac{1}{M K}\left\{\sum_{m=1}^{M} \sum_{k=1}^{K}\left[\left(\hat{v}_{k m}^{3}\right)^{2}-\sum_{u=1}^{2}\left(f_{k m}^{u} / f_{k m}\right)^{2} \hat{s}_{k m}^{u 33}\right]\right\}
$$

15 This assumption can be relaxed. The SE effect can be identified, if we assume that $\mathrm{E}\left(\eta_{\mathrm{km}}\right)=\mu_{\mathrm{k}}+\mu_{\mathrm{m}}$. This is also a necessary condition for identification. 
In the second step we estimate the variance matrix (5.25) and estimate the parameters by GLS.

Our estimation procedure based on (5.23) can be compared with the 2SLS procedure. With 2SLS the endogenous regressor is replaced by its projection on the exogenous variables. Of course, in (5.23) this projection is $\mathrm{f}_{\mathrm{km}}^{2} / \mathrm{f}_{\mathrm{km}}$. Note that in $(5.23)$ the dependent variable is also projected on the exogenous variables, which explains why the usual distribution theory for 2SLS does not apply.

The GLS estimates for regression (5.23) and the regressions for the other transitions are reported in Table 5. A comparison with the results in Table 3 shows, that the parameter estimates for the destination states 'welfare without SE' and 'welfare with SE' are almost identical in the two tables. Also the duration effects in the transition intensity to the state 'out-of-welfare' do not differ by much between these tables. The only significant differences are in the region effects and the effect of SE. Eliminating unobserved differences between the SE-participants and the non-participants makes the transition intensity to the state 'out-of-welfare' significantly smaller in the Walloon provinces as compared to Flanders. More importantly, the effect of SE is negative (and insignificant) in Table 5, while it was significantly positive in Table 3 . We conclude that the latter effect is due to selection of welfare recipients with favorable prospects into SE.

\section{INSERT TABLE 5 APPROXIMATELY HERE}

Note that the chi-square test does not reject the model in Table 5 against the saturated model. After correction for differences in the unobservables, there is no evidence of non-proportionality as in Table 4.

\section{The Effect of Temporal Aggregation}

The methods used in this paper rely on grouping of durations in a relatively small number of intervals. Although the models for the transition intensities allow for an interpretation in continuous time, the specification of the duration dependence may be coarse with a few duration intervals. For that reason, we estimate (5.23) and the regressions for the other two transition intensities with 8 instead of 4 duration intervals. The results are reported in Table 6.

\section{INSERT TABLE 6 APPROXIMATELY HERE}

Upon comparison with the estimates of Table 5 we conclude, that only the estimates of the duration effects differ between these two tables. In particular, the estimate of the SE-effect is similar to that in Table 5. Note that the model is rejected against the saturated model. If we allow the duration effects to be different in Brussels we obtain a specification that is not rejected. The estimated SE-effect is virtually identical to that in Table 6.

We conclude that the estimate of the SE-effect is robust under temporal aggregation.

\section{Conclusion}


In this paper we estimate the effect of participation in social employment (SE) on welfare duration in Belgium. For this purpose we extend the minimum chi-square approach that Cockx (1995) proposed for the analysis of grouped duration data. First, we show that the time-varying participation in SE can be modeled in a competing risks framework. Secondly, by allowing for a specification error, that captures the effect of unobservables on the transition rates, we can allow for selectivity with respect to participation in SE. Finally, if we assume that the unobserved group effects are on average the same in all duration intervals, we can project the participation dummy and the dependent variable on the region, to obtain an estimate of the SE-effect corrected for non-random selection into SE.

In Belgium the level of the subsidy to SE varies between regions in a way that is unrelated to the variable of interest, i.e. the probability of leaving welfare. As this subsidy is likely to affect the rates of participation in SE, this variation in the subsidy level can be viewed as exogenous. This exogenous variation enables us to identify the effect of SE with minimal parametric assumptions. As such, we comply with LaLonde's (1986), and Fraker and Maynard's (1987) critique on the non-experimental evaluation methodology.

The estimation results can be summarized as follows ${ }^{16}$. If we correct for selection on observables only (Section 5.3, Table 3) participation in SE reduces the median welfare spell from 13.1 to 11.6 months ${ }^{17}$. The corresponding coefficient is significantly different from 0 . If we correct for selection on unobservables, we find evidence for substantial creaming in the selection process. Participation in SE is now found to reduce the exit rate from welfare, be it that the effect is not significantly different from 0 . The median duration of a welfare spell is 12.5 months for nonparticipants and 14.8 months for participants in SE.

These results are in line with the expectations. As argued in Section 2, welfare agencies (WA) face adverse incentives. Since the welfare recipient who is in SE will eventually become entitled to unemployment benefits, and will therefore no longer depend on the WA, the WA has no incentive to enhance the professional integration of the participants in SE. Moreover, since the SE is heavily subsidized, the WA has an incentive to enroll welfare recipients into the program and to keep them employed in order to do jobs requiring few qualifications at a very low cost. The more the WA selects the most productive welfare recipients, the more it can profit from this program. With the current incentives to the WA's it is very unlikely that the welfare recipient gain from participation in SE.

\section{References}

Amemiya, Takeshi and Nold, Frederick (1975), "A Modified Logit Model", Review of Economics and Statistics, 57, 255-257.

\footnotetext{
16 We discuss the estimates reported in Tables 3 and 5.

17 These median durations refer to a welfare recipient in Flanders, who is selected into SE after 6 months.
} 
Angrist, Joshua D. (1990), "Lifetime Earnings and the Vietnam Era Draft Lottery: Evidence from social insurance Administrative Records", American Economic Review, 80 , no. 3, 313-336.

Angrist, Joshua D. (1992), "What Can be Learned from a Natural Experiment", paper prepared for the Amsterdam Conference on Causality, November.

Angrist, Joshua D. (1993), "The Effect of Veterans Benefits on Education and Earnings", Industrial and Labor Relations Review, 46(4), July, 637-52.

Angrist, Joshua D. and Krueger, Alan B. (1991), "Does Compulsory School Attendance Affect Schooling and Earnings?", Quarterly Journal of Economics, 106, no. 4, 9791014.

Bassi, Lauri J. and Orley Ashenfelter (1986), "The Effect of Direct Job Creation and Training Programs on Low-Skilled Workers", in: Danziger, Sheldon H. and Daniel H. Weinberg (eds.), Fighting Poverty. What Works and What Doesn't?, Harvard University Press, Cambridge, Massachusetts, and London, England.

Bell, Stephan H. and Larry L. Orr (1994), "Is Subsidized Employment Cost Effective for Welfare Recipients? Experimental Evidence from Seven State Demonstrations", Journal of Human Resources, 29 (1), 42-61.

Berger, Jean-Marie (1987-92), Mémento CPAS 87-93, Kluwer - Editions Scientifiques, Zaventem.

Burtless, G. and Orr, L.L. (1986), "Are Classical Experiments Needed for Manpower Policy?", Journal of Human Resources, 21, 606-639.

Card, David and Krueger, Alan B. (1994), "Minimum Wages and Employment: A Case Study of the Fast-Food Industry in New Jersey and Pennsylvania", American Economic Review, 84, no. 4, 772-793.

Caymax, E. (1988), Tewerkstelling als alternatief voor het Bestaansminimum. Verslag van een actie-onderzoek in vijf Vlaamse Openbare Centra voor Maatschappelijk Welzijn, Hoger Instituut voor de Arbeid, Katholieke Universiteit Leuven, Leuven.

Cockx, Bart (1995), "The Analysis of Transition Data by the Minimum Chi-Square Method. An Application to Welfare Spells in Belgium", discussion paper 9508, Institut de Recherches économiques et sociales, Université Catholique de Louvain, forthcoming in The Review of Economics and Statistics..

Cox, D.R. (1972), "Regression Models and Life Tables," Journal of the Royal Statistical Society $B, 34,187-220$.

Dehaes, Viviane (1994), Leven van de bijstand. Een onderzoek naar de persistentie van armoede in Vlaanderen, CBGS-monografie, 1, Centrum voor Bevolkings en Gezinsstudiën, Brussel. 
Deschamps, Ivan (1988), La remise au travail des bénéficiares du Minimum de Moyens d'Existence. Rapport d'une recherche-action menée auprès de six C.P.A.S.-pilotes de Wallonie, Facultés Notre-Dame de la Paix, Namur.

Fraker, T. and Maynard, R. (1987), "The Adequacy of Comparison Group Designs for Evaluations of Employment-Related Programs", Journal of Human Resources, 22, 194227.

Garcia, A. (1990), La remise au travail des bénéficiaires du Minimex dans le cadre de l'article 60 \$7, Département des Sciences Politiques et Sociales, Université Catholique de Louvain, Louvain-la-Neuve.

Gueron, Judith M. (1990), "Work and Welfare: Lessons on Employment Programs", Journal of Economic Perspectives, 4(1), Winter, 79-98.

Gueron Judith M. and Edward Pauly (1991), From Welfare to Work, Russell Sage Foundation, New York.

Heckman, James J. (1992), "Randomization and social Policy Evaluation", in Manski, Charles F. and Garfinkel, Irwin (eds.), Evaluating Welfare and Training Programs, Harvard University Press, Cambridge, Massachusetts.

Imbens, Guido W. and Angrist, Joshua D. (1994), "Identification and Estimation of Local Average Treatment Effects", Econometrica, 62, no. 2, 467-475.

Imbens, Guido W. and Wilbert van der Klaauw (1993), "Evaluating the Cost of Conscription in the Netherlands," mimeo, Harvard University and NBER, and New York University.

Krueger, Alan B. (1990), "Workers' Compensation Insurance and the Duration of Workplace Injuries", NBER Working Paper Series, no.3253.

Lalonde, R. (1986), "Evaluating the Econometric Evaluations of Training Programs with Experimental Data", American Economic Review, 79, 604-620.

Lancaster, Tony (1990), The Econometric Analysis of Transition Data, Cambridge University Press, Cambridge.

Lescrauwaet, Danny (1988), Tewerkstelling van Bestaansminimum-gerechtigden. Verslag van een actie-onderzoek gehouden in het guest Brussels, Hoger Instituut voor de Arbeid, Katolieke Universiteit Leuven, Leuven.

Meyer, Bruce D. (1989), "A Quasi-Experimental Approach to the Effects of Unemployment Insurance", NBER Working Paper Series, no. 3159.

Meyer, Bruce D., Viscusi, W. Kip and Durbin, David L. (1990), "Workers' Compensation and Injury Duration: Evidence from a Natural Experiment", NBER Working Paper Series, no. 3494. 
Meyer, Bruce D. (1995), "Natural and Quasi-Experiments in Economics", Journal of Business and Economic Statistics, 13(2), April, 151-161.

Moffitt, Robert (1992), "Incentive Effects of the U.S. Welfare system: A Review", Journal of Economic Literature, 30 (March), 1-61.

O.C.M.W.-Visies (1993), "Het Bijzonder Fonds voor Maatschappelijk Welzijn: een overzicht van de gehanteerde criteria", O.C.M.W.-Visies, 1, 14-22.

Parks, Richard W. (1980), "On the Estimation of Multinomial Logit Models from Relative Frequency Data", Journal of Econometrics, 13, 293-303.

Prentice, R. L. and L.A. Gloeckler (1978), " Regression Analysis of Grouped Survival Data with Application to Breast Cancer Data," Biometrics, 34, 57-67.

Ridder, Geert (1986), "An Event History Approach to the Evaluation of Training, Recruitment and Employment Programmes", Journal of Applied Econometrics, 1(2), 109-126.

Van de Velde, Veerle (1990), Wat na de sociale tewerkstelling? Evaluatie van de toepassing van art. 60 par. 7 van de organieke wet op het OCMW, Hoger Instituut voor de Arbeid, Katolieke Universiteit Leuven, Leuven.

Van Langendonck, J. (1991), Handboek Sociale Zekerheid, Acco, Leuven.

Van Meensel, Rien and Rikkie Heeman (1992), Tewerkstelling en Opleiding van Kansarmen, Hoger Instituut voor de Arbeid, KU Leuven, Leuven.

Wouters, Martine, Rien Van Meensel and Ides Nicaise (1994), De TOK-projecten en hun cursisten, drie jaar later. Follow-up onderzoek van de projecten van 1989, Hoger Instituut voor de Arbeid, KU Leuven, Leuven. 
Table 1: The Proportion of the Regional Fund allocated to SE

\begin{tabular}{ccccc} 
period & Brussels & Flanders & \multicolumn{2}{c}{$\begin{array}{c}\text { Walloon Provinces } \\
<50,000\end{array}$} \\
& & & inhabitants & inhabitants \\
$1986-1988$ & $0 \%$ & $10 \%$ & $0 \%$ & $0 \%$ \\
$1989-1991$ & $0 \%$ & $15 \%$ & $5 \%$ & $5.5 \%$ \\
1992 & $0 \%$ & $18 \%$ & $6 \%$ & $6 \%$
\end{tabular}

Source: Berger (1987-92) and O.C.M.W.-Visies (1993). 
Table 2: $\quad$ Population characteristics

\begin{tabular}{|c|c|c|}
\hline & $\begin{array}{c}\text { all welfare spells } \\
\text { (including SE) }\end{array}$ & $\begin{array}{c}\text { spells with some time in } \\
\text { SE }\end{array}$ \\
\hline number of spells & 80,621 & 2,813 \\
\hline average age in years & 30.0 & 30.9 \\
\hline male & $47.6 \%$ & $32.1 \%$ \\
\hline Belgian & $92.2 \%$ & $94.3 \%$ \\
\hline $\begin{array}{l}\text { Children } \\
\text { dependent children present } \\
\text { number of children }\end{array}$ & $\begin{array}{c}39.2 \% \\
1.8\end{array}$ & $\begin{array}{l}51.7 \% \\
1.8\end{array}$ \\
\hline $\begin{array}{l}\text { Marital status } \\
\text { unmarried } \\
\text { married } \\
\text { widow(er) } \\
\text { divorced }\end{array}$ & $\begin{array}{c}45.3 \% \\
30.6 \% \\
1.2 \% \\
22.8 \%\end{array}$ & $\begin{array}{c}37.5 \% \\
38.5 \% \\
0.6 \% \\
23.4 \%\end{array}$ \\
\hline $\begin{array}{l}\text { Household type } \\
\text { living alone } \\
\text { married / cohabiting. } \\
\text { unmarred / cohabiting }\end{array}$ & $\begin{array}{l}69.5 \% \\
10.1 \% \\
20.4 \%\end{array}$ & $\begin{array}{c}73.1 \% \\
9.8 \% \\
17.2 \%\end{array}$ \\
\hline $\begin{array}{l}\text { Region } \\
\text { Flanders } \\
\text { Walloon Provinces } \\
\text { Brussels }\end{array}$ & $\begin{array}{l}39.4 \% \\
47.0 \% \\
13.6 \%\end{array}$ & $\begin{array}{l}59.4 \% \\
25.7 \% \\
14.9 \%\end{array}$ \\
\hline $\begin{array}{l}\text { Size of municipality } \\
\quad>100,000 \\
50-100,000 \\
<50,000\end{array}$ & $\begin{array}{l}36.0 \% \\
18.3 \% \\
45.7 \%\end{array}$ & $\begin{array}{l}28.4 \% \\
18.1 \% \\
53.5 \%\end{array}$ \\
\hline $\begin{array}{l}\text { Welfare spells (months) } \\
\text { median welfare duration } \\
\text { median SE duration } \\
\text { median duration until SE }\end{array}$ & $\begin{array}{l}4.9 \\
- \\
-\end{array}$ & $\begin{array}{c}13.1 \\
6.3 \\
6.0\end{array}$ \\
\hline
\end{tabular}


Table 3: $\quad$ GLS estimates of the parameters of the transition intensities (standard error in parentheses)

\section{Destination state $v$}

\begin{tabular}{|c|c|c|c|}
\hline & \\
\hline & $\begin{array}{l}\text { 1: Welfare } \\
\text { without SE }\end{array}$ & $\begin{array}{l}\text { 2: Welfare } \\
\text { with SE }\end{array}$ & 3: Out of welfare \\
\hline \multicolumn{4}{|l|}{$\begin{array}{l}\text { Duration interval } \\
\text { (months) }\end{array}$} \\
\hline $0-3\left(\gamma_{1}^{\mathrm{v}}\right)$ & $\begin{array}{l}-3.307 * * * \\
(.210)\end{array}$ & $\begin{array}{l}-4.977 * * * \\
(.064)\end{array}$ & $\begin{array}{l}-1.838 * * * \\
(.095)\end{array}$ \\
\hline $3-6\left(\gamma_{2}^{\mathrm{v}}-\gamma_{1}^{\mathrm{v}}\right)$ & $\begin{array}{l}-.224 \\
(.236)\end{array}$ & $\begin{array}{l}-.011 \\
(.095)\end{array}$ & $\begin{array}{l}-.341 * * * \\
(.108)\end{array}$ \\
\hline $6-12\left(\gamma_{3}^{\mathrm{v}}-\gamma_{1}^{\mathrm{v}}\right)$ & $\begin{array}{l}-.610 * * \\
(.236)\end{array}$ & $\begin{array}{l}-.035 \\
(.095)\end{array}$ & $\begin{array}{l}-.465 * * * \\
(.107)\end{array}$ \\
\hline $12-24\left(\gamma_{4}^{\mathrm{v}}-\gamma_{1}^{\mathrm{v}}\right)$ & $\begin{array}{l}-.693 * * \\
(.265)\end{array}$ & $\begin{array}{l}.089 \\
(.107)\end{array}$ & $\begin{array}{l}-.579 * * * \\
(.109)\end{array}$ \\
\hline \multicolumn{4}{|l|}{ Region } \\
\hline Walloon Prov. $\left(\beta_{2}^{\mathrm{v}}\right)$ & $\begin{array}{l}.448 * * \\
(.184)\end{array}$ & $\begin{array}{l}-1.190 * * * \\
(.086)\end{array}$ & $\begin{array}{l}-.016 \\
(.092)\end{array}$ \\
\hline Brussels $\left(\beta_{3}^{\mathrm{v}}\right)$ & $\begin{array}{l}-.364 \\
(.318)\end{array}$ & $\begin{array}{l}-.359 * * * \\
(.104)\end{array}$ & $\begin{array}{c}.086 \\
(.095)\end{array}$ \\
\hline $\begin{array}{c}\text { SE-effect } \\
\alpha^{23}\end{array}$ & - & - & $\begin{array}{l}.224 * * \\
(.093)\end{array}$ \\
\hline $\begin{array}{l}\text { Unobserved vars. } \\
\qquad \hat{\sigma}^{1 \mathrm{vw}} \\
\hat{\sigma}^{2 \mathrm{vw}}\end{array}$ & $\begin{array}{l}0 \\
-\end{array}$ & $\overline{0}$ & $\begin{array}{l}0.00868 \\
0.01986\end{array}$ \\
\hline $\begin{array}{l}\text { Weighted sum of } \\
\text { squared residuals } \\
\text { (degrees of freedom) } \\
\text { P-value }\end{array}$ & & $\begin{array}{l}72.54 \\
(29) \\
.00\end{array}$ & \\
\hline
\end{tabular}

* $\quad$ significant at the $10 \%$ level

** significant at the $5 \%$ level

*** significant at the $1 \%$ level 
Table 4: $\quad$ GLS estimates of the parameters of the transition intensities: SE effect dependent on time in welfare (standard errors in parentheses)

Destination state $v$

\begin{tabular}{|c|c|c|c|}
\hline & & & \\
\hline & $\begin{array}{l}\text { 1: Welfare } \\
\text { without SE }\end{array}$ & $\begin{array}{c}\text { 2: Welfare } \\
\text { with SE } \\
\end{array}$ & 3: Out of welfare \\
\hline \multicolumn{4}{|l|}{$\begin{array}{l}\text { Duration interval } \\
\text { (months) }\end{array}$} \\
\hline $0-3\left(\gamma_{1}^{\mathrm{v}}\right)$ & $\begin{array}{l}-3.091 * * * \\
(.120)\end{array}$ & $\begin{array}{l}-4.977 * * * \\
(.041)\end{array}$ & $\begin{array}{l}-1.790 * * * \\
(.064)\end{array}$ \\
\hline $3-6\left(\gamma_{2}^{\mathrm{v}}-\gamma_{1}^{\mathrm{v}}\right)$ & $\begin{array}{l}-.224 \\
(.150)\end{array}$ & $\begin{array}{l}-.011 \\
(.060)\end{array}$ & $\begin{array}{l}-.312 * * * \\
(.078)\end{array}$ \\
\hline $6-12\left(\gamma_{3}^{\mathrm{v}}-\gamma_{1}^{\mathrm{v}}\right)$ & $\begin{array}{l}-.609 * * * \\
(.150)\end{array}$ & $\begin{array}{l}-.035 \\
(.061)\end{array}$ & $\begin{array}{l}-.510 * * * \\
(.078)\end{array}$ \\
\hline $12-24\left(\gamma_{4}^{\mathrm{v}}-\gamma_{1}^{\mathrm{v}}\right)$ & $\begin{array}{l}-.621 * * * \\
(.169)\end{array}$ & $\begin{array}{l}.088 \\
(.068)\end{array}$ & $\begin{array}{l}-.779 * * * \\
(.079)\end{array}$ \\
\hline \multicolumn{4}{|l|}{ Region } \\
\hline Walloon Prov. $\left(\beta_{2}^{\mathrm{v}}\right)$ & $\begin{array}{l}.462 * * * \\
(.117)\end{array}$ & $\begin{array}{l}-1.190 * * * \\
(.055)\end{array}$ & $\begin{array}{l}-.008 \\
(.059)\end{array}$ \\
\hline Brussels $\left(\beta_{3}^{v}\right)$ & $\begin{array}{l}-.350 * \\
(.202)\end{array}$ & $\begin{array}{l}-.360 * * * \\
(.066)\end{array}$ & $\begin{array}{c}.087 \\
(.060)\end{array}$ \\
\hline \multicolumn{4}{|l|}{$\begin{array}{l}\text { SE-effect by duration } \\
\text { interval }\end{array}$} \\
\hline $0-3\left(\alpha_{1}^{23}\right)$ & - & - & $\begin{array}{l}-.020 \\
(.119)\end{array}$ \\
\hline $3-6\left(\alpha_{2}^{23}\right)$ & - & - & $\begin{array}{l}-.165 \\
(.121)\end{array}$ \\
\hline $6-12\left(\alpha_{3}^{23}\right)$ & - & - & $\begin{array}{l}.197 * \\
(.113)\end{array}$ \\
\hline $12-24\left(\alpha_{4}^{23}\right)$ & - & - & $\begin{array}{l}.894 * * * \\
(.120)\end{array}$ \\
\hline $\begin{array}{l}\text { Unobserved vars. } \\
\qquad \hat{\sigma}^{1 \mathrm{ww}} \\
\hat{\sigma}^{2 \mathrm{vw}}\end{array}$ & $\begin{array}{l}0 \\
-\end{array}$ & $\begin{array}{l}- \\
0\end{array}$ & $\begin{array}{l}0.00868 \\
0.01986\end{array}$ \\
\hline $\begin{array}{l}\text { Weighted sum of } \\
\text { squared residuals } \\
\text { (degrees of freedom) } \\
\text { P-value }\end{array}$ & & $\begin{array}{l}26.32 \\
(26) \\
.45\end{array}$ & \\
\hline
\end{tabular}

* $\quad$ significant at the $10 \%$ level

** significant at the $5 \%$ level

*** significant at the $1 \%$ level 
Table 5: GLS estimates of the parameters of the transition intensities with participation rate in SE instead of participation indicator (standard errors in parentheses)

Destination state $v$

\begin{tabular}{|c|c|c|c|}
\hline & \multicolumn{3}{|c|}{ Destination state $v$} \\
\hline & $\begin{array}{l}\text { 1: Welfare } \\
\text { without SE }\end{array}$ & $\begin{array}{c}\text { 2: Welfare } \\
\text { with SE }\end{array}$ & 3: Out of welfare \\
\hline \multicolumn{4}{|l|}{$\begin{array}{l}\text { Duration interval } \\
\text { (months) }\end{array}$} \\
\hline $0-3\left(\gamma_{1}^{\mathrm{v}}\right)$ & $\begin{array}{l}-3.095 * * * \\
(.13)\end{array}$ & $\begin{array}{l}-4.976^{* * * *} \\
(.044)\end{array}$ & $\begin{array}{l}-1.716 * * * \\
(.028)\end{array}$ \\
\hline $3-6\left(\gamma_{2}^{v}-\gamma_{1}^{v}\right)$ & $\begin{array}{l}-.222 \\
(.162)\end{array}$ & $\begin{array}{l}-.011 \\
(.065)\end{array}$ & $\begin{array}{l}-.321 * * * \\
(.025)\end{array}$ \\
\hline $6-12\left(\gamma_{3}^{\mathrm{v}}-\gamma_{1}^{\mathrm{v}}\right)$ & $\begin{array}{l}-.608 * * * \\
(.162)\end{array}$ & $\begin{array}{l}-.035 \\
(.065)\end{array}$ & $\begin{array}{l}-.510 * * * \\
(.033)\end{array}$ \\
\hline $12-24\left(\gamma_{4}^{\mathrm{v}}-\gamma_{1}^{\mathrm{v}}\right)$ & $\begin{array}{l}-.614 * * * \\
(.183)\end{array}$ & $\begin{array}{l}.088 \\
(.074)\end{array}$ & $\begin{array}{l}-.710 * * * \\
(.051)\end{array}$ \\
\hline \multicolumn{4}{|l|}{ Region } \\
\hline Walloon Prov. $\left(\beta_{2}^{\mathrm{v}}\right)$ & $\begin{array}{l}.469 * * * \\
(.127)\end{array}$ & $\begin{array}{l}-1.191 * * * \\
(.059)\end{array}$ & $\begin{array}{l}-.116 * * * \\
(.033)\end{array}$ \\
\hline Brussels $\left(\beta_{3}^{v}\right)$ & $\begin{array}{l}-.349 \\
(.219)\end{array}$ & $\begin{array}{l}-.360 * * * \\
(.071)\end{array}$ & $\begin{array}{l}-.008 \\
(.026)\end{array}$ \\
\hline \multicolumn{4}{|l|}{ SE-effect } \\
\hline$\alpha^{23}$ & - & - & $\begin{array}{l}-.256 \\
(.805)\end{array}$ \\
\hline \multicolumn{4}{|l|}{ Unobserved vars } \\
\hline $\begin{array}{l}\hat{\sigma}^{1 \mathrm{ww}} \\
\hat{\sigma}^{2 \mathrm{ww}}\end{array}$ & $\begin{array}{l}0 \\
-\end{array}$ & $\overline{0}$ & $\begin{array}{l}- \\
-\end{array}$ \\
\hline$\hat{\sigma}^{33}$ & - & - & .000420 \\
\hline $\begin{array}{l}\text { Weighted sum of } \\
\text { squared residuals } \\
\text { (degrees of freedom) }\end{array}$ & & $\begin{array}{c}20.13 \\
(17)\end{array}$ & \\
\hline P-value & & .27 & \\
\hline
\end{tabular}

* $\quad$ significant at the $10 \%$ level

** significant at the $5 \%$ level

*** significant at the $1 \%$ level 
Table 6: GLS estimates of the parameters of the transition intensities with participation rate in SE instead of participation indicator: 8 duration intervals (standard errors in parentheses)

\section{Destination state $v$}

\begin{tabular}{ll}
\hline 1: Welfare & 2: Welfare with 3: Out of welfare \\
without SE & SE
\end{tabular}

\begin{tabular}{|c|c|c|c|}
\hline \multicolumn{4}{|l|}{$\begin{array}{l}\text { Duration interval } \\
\text { (months) }\end{array}$} \\
\hline $0-3\left(\gamma_{1}^{\mathrm{v}}\right)$ & $\begin{array}{c}-3.103 * * * \\
(.148)\end{array}$ & $\begin{array}{l}-4.977 * * * \\
(0.052)\end{array}$ & $\begin{array}{c}-1.706 * * * \\
(.015)\end{array}$ \\
\hline $3-6\left(\gamma_{2}^{v}-\gamma_{1}^{v}\right)$ & $\begin{array}{l}-.234 \\
(.191)\end{array}$ & $\begin{array}{l}-.011 \\
(.077)\end{array}$ & $\begin{array}{l}-.335^{* * *} \\
(.015)\end{array}$ \\
\hline $6-9\left(\gamma_{3}^{v}-\gamma_{1}^{v}\right)$ & $\begin{array}{l}-.211 \\
(.190)\end{array}$ & $\begin{array}{l}-.087 \\
(.092)\end{array}$ & $\begin{array}{l}-.619 * * * \\
(.023)\end{array}$ \\
\hline $9-12\left(\gamma_{4}^{\mathrm{v}}-\gamma_{1}^{\mathrm{v}}\right)$ & $\begin{array}{l}-.118 \\
(.195)\end{array}$ & $\begin{array}{l}-.115 \\
(.109)\end{array}$ & $\begin{array}{l}-.532 * * * \\
(.027)\end{array}$ \\
\hline $12-15\left(\gamma_{5}^{\mathrm{v}}-\gamma_{1}^{\mathrm{v}}\right)$ & $\begin{array}{l}-.205 \\
(.210)\end{array}$ & $\begin{array}{l}-.047 \\
(.124)\end{array}$ & $\begin{array}{l}-.868 * * * \\
(.036)\end{array}$ \\
\hline $15-18\left(\gamma_{6}^{\mathrm{v}}-\gamma_{1}^{\mathrm{v}}\right)$ & $\begin{array}{l}-.176 \\
(.226)\end{array}$ & $\begin{array}{l}-.070 \\
(.145)\end{array}$ & $\begin{array}{l}-.975 * * * \\
(.042)\end{array}$ \\
\hline $18-21\left(\gamma_{7}^{\mathrm{v}}-\gamma_{1}^{\mathrm{v}}\right)$ & $\begin{array}{l}-.214 \\
(.263)\end{array}$ & $\begin{array}{l}-.097 \\
(.175)\end{array}$ & $\begin{array}{l}-.977 * * * \\
(.047)\end{array}$ \\
\hline $21-24\left(\gamma_{8}^{\mathrm{v}}-\gamma_{1}^{\mathrm{v}}\right)$ & $\begin{array}{l}-.207 \\
(.304)\end{array}$ & $\begin{array}{l}-.225 \\
(.222)\end{array}$ & $\begin{array}{l}-.936 * * * \\
(.053)\end{array}$ \\
\hline \multicolumn{4}{|l|}{ Region } \\
\hline Walloon Prov. $\left(\beta_{2}^{\mathrm{v}}\right)$ & $\begin{array}{l}.472 * * * \\
(.119)\end{array}$ & $\begin{array}{c}-1.180 * * * \\
(.069)\end{array}$ & $\begin{array}{l}-.112 * * * \\
(.017)\end{array}$ \\
\hline Brussels $\left(\beta_{3}^{\mathrm{v}}\right)$ & $\begin{array}{l}-.128 \\
(.191)\end{array}$ & $\begin{array}{l}-.374 * * * \\
(.085)\end{array}$ & $\begin{array}{l}-.020 \\
(.018)\end{array}$ \\
\hline $\begin{array}{c}S E \text {-effect } \\
\alpha^{23}\end{array}$ & - & 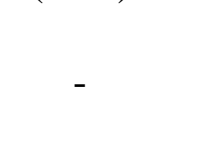 & $\begin{array}{l}-.171 \\
(.502)\end{array}$ \\
\hline $\begin{array}{l}\text { Weighted sum of } \\
\text { squared residuals } \\
\text { (degrees of freedom) } \\
\text { P-value }\end{array}$ & & $\begin{array}{c}67.463 \\
(41)\end{array}$ & \\
\hline
\end{tabular}

* $\quad$ significant at the $10 \%$ level

** significant at the $5 \%$ level

*** significant at the $1 \%$ level 